\title{
A Study of the Effects of Collaborative Writing on the Development of Chinese Senior High School Students' Discourse Competence
}

\author{
Xuan Teng (Corresponding author) \\ Foreign Studies College, Hunan Normal University \\ Changsha, China \\ E-mail: xuanteng@hunnu.edu.cn
}

Xinhui Zhou

Foreign Studies College, Hunan Normal University

Changsha, China

Received: July 1, 2020

Accepted: August 5, 2020

Published: August 24, 2020

doi:10.5296/ijl.v12i4.17376

URL: https://doi.org/10.5296/ijl.v12i4.17376

\begin{abstract}
Although writing is an important skill, the writings of many high school students in China in general lack cohesion and coherence. As the Chinese National English Curriculum Standards for High School (2017) mentioned, the cultivation of senior high school students' discourse competence is of great importance. However, traditional teaching methods paid little attention to student writing at the discourse level. In recent years, collaborative writing has been introduced to writing classes, and most researchers examined its effect on students' writing interests andwriting scores. The purpose of this study is therefore to investigate whether collaborative writing has a positive effect on students' discourse competence. Specifically, it seeks to explore the effect of collaborative writing on students' textual cohesion and textual coherence.Students' writing assignments were analyzed using Coh-Metrix 3.0. Their interaction was analyzed through the perspective of sociocultural theory. The results showed that collaborative writing effectively promoted senior high school students' textual cohesion and coherence. It also mediated their co-construction of knowledge about discourse through peer-peer scaffolding, which led to higher level of discourse competence.
\end{abstract}

Keywords: Collaborative writing, Discourse competence, Cohesion, Coherence 


\section{Introduction}

Writing allows students to express their thoughts and feelings in written form through the use of what they have learnt in English classes. Due to the influence of their native language, most Chinese students'work consists of sentences that lack cohesion and coherence, which hinders the comprehensibility of the written discourse. In addition, theirproficiency in deploying cohesive devices and skills in creating a consistent textare indicative of the levels of their writing ability.Therefore, it is important that teachers find an effective way to help students produce more cohesive and coherent discourse, and improve their writing ability.Findings of a number of studies suggested that collaborative writing is beneficial for the improvement of students' writing ability (Zimmet, 2000; Storch, 2005; Wigglesworth \& Storch, 2009; Aminloo, 2013; Challob, 2016). Collaborative writing differs from traditional approach to teaching writing in that it emphasizes on the process of writing and the interaction betweenstudents and students. From the viewpoint of the Sociocultural theory, collaboration enables students to engage in scaffolding in which they provide assistance to each other through the process of solving language problems together. They are novices when they work individually, and are experts when working collaboratively (Donato, 1994).

Due to the benefits of collaborative writing on students' writing abilities, it is very likely to be an efficient method to promote their discourse competence. However, thus far there are few studies that focus on the effect of collaborative writing on students' discourse competence. As a result, this study attempts to apply collaborative writing to Chinese high school students' writing class to examine its effectiveness. During collaborative writing, teachers play the roles of facilitators and resource-providers, which is consistent with the requirement of the Chinese National English Curriculum Standards for High School (2017). According to the curriculum, foreign language teaching should pay close attention to the learning process, and advocate experiential learning and participation. In this study, it is through the input provided by the teacher and the interaction between the students that their written work is of better quality in terms of discourse features.

This study has several significances. First and foremost, more evidence will be provided concerning Sociocultural theory in the field of writing teaching. Secondly, from the perspective of pedagogy, this approach sheds light on the application of collaborative writing to senior high school writing class. Finally, this study investigates the effect of collaborative writing on students' discourse competence, which could provide new direction for senior high school teachers in guiding students' writing.

\section{Literature Review}

Writing is the process of thinking and expressing ideas (Zemal, 1982; Urquhart \& McIver, 2005), and writing ability is essential for senior high school students. During the writing process, students not only combine words, sentences, and paragraphs together, they also choose, extract, process and integrate the knowledge they have accumulated.As a result, writing ability is not simply the output of scattered sentences, but the ability to produce coherent and cohesive text. According to Bereiter (1987), there are five components of writing ability: the ability to the thought of writing, the ability to operate the writing process, 
the ability to convey ideas, proficiency in the use of a variety of expressions, and the ability to evaluate. It is generally agreed that writing ability involves not only grammatical accuracy but also the ability of organization, logic and cohesion.

\subsection{Collaborative Writing}

Collaborative writing refers to two or more writers make a composition together (Belcher, 1990; Lowry et al., 2004; Storch, 2011). It mainly focuses on students' writing process rather than the final composition. There are three prominent features of collaborative writing, notably real interaction, shared responsibility, and one composition (Ede \& Lunsford, 1990). During student interaction, different interaction patternswere found to be influential in terms of writing quality. Particularly, Storch (2002) distinguished different patterns using the index of equality and mutuality. Equality refers to the equal distribution of turns among collaborative partners and their contribution to the content, while mutuality means the degree of engagement among the participator and other group members. Storch found that in total there are four types of patterns, namely collaborative, dominant/dominant, dominant/passive, and expert/novice. Among these four patterns, the collaborative and expert/novice patterns seemed to promote students' writing quality to the maximum extent.Li and Zhu (2017b) further demonstrated that written work produced by groups with high degree of engagement were in general more coherent and clearer in rhetorical structure.

Many researchers found that collaborative writing could improve students' writing quality (Rayers, 1987; Ross, 1995; O' Donnell etal., 1985, Strobl, 2013; Bikowsk \& Vithanage, 2016). For example, Hsu and Lo (2018) found that students engaging in wiki-mediated collaborative writing produced individual writing in L2 of better content quality and linguistic accuracy. Aydin and Yildiz (2014), along with Wigglesworth and Storch (2009), found that collaborative writing impacted positively on writing accuracy. Kessler et al. (2012) suggested that students paid more attention to meaning than form, and their accuracy on grammar has increased when they were constructing compositions using wiki-based word processing tool in collaborative writing. Furthermore, Abrams (2019) found that collaboration-oriented group could construct written text with more related content and higher coherence. In addition, collaborative writing could aid in the development of language skills (Watanabe \& Swain, 2007; Elola, 2010; Kessler et al., 2012; Liu \& Lan, 2016). For example, it facilitated students' memory of syntactic information (Liu \& Lan, 2016; Watanabe \& Swain, 2007) and enhance theirlanguage cognition and acquisition (Swain, 2006). The interaction among students in collaborative writing can help students solve their problems in writing (Yeh, 2014), plan and construct their writing (Kormos, 2014; Storch, 2011) and generate and consolidate their existing knowledge (Wigglesworth \& Storch, 2012).

Another topic often investigated in relation to collaborative writing is peer feedback. Feedback means providing suggestions for writers to revise their writing. In traditional writing class, students receive feedback mainly from their teachers. Nevertheless, as Mangelsdorf (1992) suggested, peer feedback should be added in writing teaching process to enable group members to evaluate their partners' writing (Falchikov, 1995) and provide revision suggestion.Peer feedback plays an essential role in collaborative writing (Grami, 
2012). In particular, students incorporated peer feedback into their writing if their interaction is collaborative (Nelson \& Murphy, 1993). The quality of composition revision was also closely associated with writers' writing competence and the efficacy of reader feedback (Hedgcock \& Lefkowitz, 1992). More importantly, peer feedback helped to increasestudent writing motivation (Dheram,1995; Clifford, 1981; Mo, 2007), confidence and interest in writing (King, 1979; Cai, 2011), as well as critical thinking, learner autonomy and social interaction (Yang et al., 2006).

\subsection{Discourse Competence}

Discourse competence has long been viewed as an important part of communicative competence (Hymes, 1972; Canale\& Swain, 1980; Celce-Murcia et al., 1995). It refers to the ability to link words together to form a text according to the rules of cohesion and coherence (Canale\& Swain, 1980; Kaplan \& Knutson, 1993) and the comprehensive ability of the speakers to apply language in the level of discourse (Carter \& McCarthy, 1997). In China, Wen (1999) pointed out that discourse competence refers to the knowledge of forming discourse into cohesive and coherent whole texts, and the ability to use this kind of knowledge.

Cohesion and coherence are the two important components of discourse competence (Celce-Murcia et al., 1995; Zhuang, 2011). In particular, cohesion is by and large regarded as a linguistic phenomenon on the surface of discourse. For example, Halliday and Hasan (1976) pointed out that cohesion is a general term of grammar and lexical means that combine language elements together. Hoey(1991) similarly noted that cohesion is "a property of a text whereby certain grammatical or lexical features of the sentences of the text connect them to other sentences in the text" (p. 260).In the discourse competence model proposed by Celce-Murcia, Dornyei and Thurell (1995), cohesion includes anaphora, cataphora, substitution, omission, connection and so on. Cohesion makes scattered sentences linked into a complete text. Overall, cohesion lies in the surface of a discourse and is a tangible net of text surface structure distribution (Huang, 1988).

Coherence refers to the sematic association in a discourse. Different from cohesion, coherence is an invisible network of discourse and the fundamental constituent attribute of discourse (Werth, 1999). Coherence means the purpose of expressed language should be consistent before and after (Celce-Murcia, Dornyei and Thurell, 1995).It also should be consistent in new and old information as well as time and space. Coherence in a broad sense is a semantic concept that includes pragmatic factors (Zhang, 2006). If sentences in a discourse were connected by different cohesive devices and the context and register were consistent, this discourse is coherent (Halliday \& Hasan, 2007). In sum, coherence isthe sematic connection in a discourse and the intangible net that combines scattered sentences into a complete discourse.

\subsection{Theoretical Bases}

Two theories were used as the theoretical basis of this study, namely the Sociocultural theory, and the Interaction theory. The Sociocultural theory, proposed by psychologist Vygotsky, 
emphasizes that language is a kind of sociocultural behavior, and the process of human cognitive development contains two levels, notably the social level and the individual level (Vygotsky, 1978). There are four basic concepts in this theory: mediation, internalization, Zone of Proximal Development (ZPD) and scaffolding. According to Lantolf and Thorne (2006), Mediation is "the process through which humans deploy culturally constructed artifacts, concepts, and activities to regulate (i.e., gain voluntary control over and transform) the material world or their own and each other's social and mental activity" (p. 79). Internalization is "the process through which members of communities of practice appropriate the symbolic artifacts used in communicative activity and convert them into psychological artifacts that mediate their mental activity" (p. 90). Moreover, According to Vygotsky (1978), ZPD is "the distance between the actual development level as determined by independent problem solving and the level of potential development as determined through problem solving under adult guidance, or in collaboration with more capable peers" (p. 86). Scaffolding was first proposed by Wood, Bruner and Ross (1976). It refers to the process of supporting, which enable children or novice to solve a problem, finish a task or achieve a goal that are beyond the scope of his or her independent efforts.

Interaction hypothesis, proposed by Michael Long in 1981, was based on input hypothesis put forward by Krashen. Interaction refers to the communication among speaker and listeners, and it can facilitate the development of interlocuters. Formal researches indicated that if there is only input or modified input for language learners, they cannot learn language effectively (Wang \& Castro, 2010; Namaziandost et al. 2018). Therefore, teachers should pay more attention to the interaction among students in class and try to give more opportunities to students to interaction with each other in order to promote their language development.

From the above literature review, it can be concluded that only a handful of existing studies (e.g., Crosthwaite, 2011) paid attention to the relationship between collaborative writing and the development of students' L2 competence at the discourse level. Therefore, the present study aims to investigate the possible benefits of collaborative writing for Chinese senior high school students' discourse competence. The research questions are as follows:

1) What effects does collaborative writing have on senior high school students' discourse competence in terms of textual cohesion?

2). What effects does collaborative writing have on senior high school students' discourse competence in terms of textual coherence?

\section{Methodology}

\subsection{Participants}

120 students in the first year of senior high school participated in this study. They are from Class 1908 and Class 1910 of a senior high school in Hunan province, China. Their average age is 15 years old. All of them have learned English for 7 years before they entered senior high school. Class 1908 is the experimental class (EC) and Class 1910 is the controlled class (CC). They are two parallel and intact classes in this school. In order to check whether their previous discourse competence in writing have significant differences before this experiment, 
pretest was carried out in 10th October 2019, and students' writing were analyzed by Cohesion Metric Tool 3.0 (abbreviated as Coh-Metrix 3.0)and SPSS 20.0to assess their cohesion and coherence level. The results showed the two classes were at the same level in terms of discourse ability. In experimental class, students were paired according to results of their pretest and there were 30 pairs in experimental class. Students with high cohesion and coherence scores are paired with those with low scores. For the purpose of ensuring the validity and reliability of this experiment, students in these two classes are taught by the same English teacher with the same materials and they had the same number of English lessons every week. In addition, the gender ratio in the two classes is almost the same. For the sake of confidentiality, the students' names were changed to code names to ensure anonymity.

\subsection{Research Instruments}

Three writing tests, including the pretest, immediate posttest and delayed posttest, were designed for both experimental class and controlled class. The subjects of composition are chosen from the National College Entrance Examination because of its high validity and reliability.Given the students' proficiency, the difficulty level of vocabulary and grammar in writing tests was adjusted. At the same time, students were provided with help and guidance from their teacher.In addition, the format of these three writing tests was kept similar to the writing tasks inthe students' textbook to reduce their cognitive burden and anxiety.

The pretests aimed to check whether the cohesion and coherence level of these students were similar and werecarried out in the first week of this study. The English writing section of 2017 college entrance examination is used as the pretest. Students from experimental class and control class were required to write the composition individually within 30 minutes. Their writings were collected and analyzed by Coh-Metrix 3.0 and SPSS 20.0. In order to check students' cohesion and coherence level after the experiment, posttests were carried out in the eighth week of this experiment. Students from experimental class and controlled class were required to finish the writing part of 2018 college entrance examination individually. The writing prompt asked the students to write a letter to a foreign friend to introduce local custom, and it was of comparable difficulty with that of the pretests. In addition, a delayed posttest was designed to check the delayed effect of collaborative writing on cohesion and coherence of students' writing. The delayed test was carried out in the tenth week, and it was based onthe English writing section of 2019 college entrance examination. Students' composition of the posttest and delayed posttest were also collected and analyzed by Coh-Metrix 3.0 and SPSS 20.0.

\subsection{Research Procedures}

This 10-week experiment is started from 8th October 2019 to 15th December 2019. There are three tests, notablythe pretest, posttest and delayed posttest during the whole process. There were 120 students from two classes in this experiment, with 60 students in each one. Class 1908 was the experimental class, while Class 1910 was the controlled class. During the experiment, the teaching conditions of the two classes were basically similar, and the only difference was the use of teaching methods. While collaborative writing was applied in the experimental class, traditional teaching method was used in the controlled class. Specifically, 
in the experimental class, the students wrote a compositioncollaboratively in pairs, while the students in the control class wrote individually. In the experimental class, students were assigned into pairs according to their pretest results, and they received peer feedback after they finished their writing in pairs, whereas students in the control class only received feedback from their teacher.

\subsection{Data Collection}

All of students' writings in these three tests will be evaluated by Coh-Metrix 3.0, a web-based text analysis tool developed by McNamara et al. (2017) from the University of Memphis. Coh-Metrix was designed to analyze cohesion and coherence and Coh-Metrix 3.0 is the latest version. It can analyze 106 lexical, grammatical and semantic features, in 11 different categories that play a prominent role in distinguishing between different texts (Biber, 1998). They are descriptive, text easability principle component scores, referential cohesion, latent sematic analysis (LSA), lexical diversity, connectives, situation model, syntactic complexity, syntactic pattern, density, word information, and readability respectively (Ye, 2015). Many studies found that the cohesion and coherence of a discourse can be accurately analyzed by the indices in Coh-Metrix (Gui, 2003; Duran et al., 2007; Landaueretal, 2007; McNamara et al., 2010). In Jiang's (2016) study, referential cohesion, connectives and LSA are three direct indicators for the analysis of cohesion, and 31 indices under these three indicators. In this study, eight indices (CRFNO 1, CRFAO 1, CRFSO 1, CRFCWO 1, LSASS 1, LSAPP1, LDTTRc, and LDTTRa) were used to analyze the cohesion level of students' writing.

According to Liang's (2006) study, there are 18 local measures and 4 global measures that can be used in Coh-Metrix for the evaluation ofthe textual coherence of a text, and among these measures, seven indices are closely related to textual coherence of students' writing. In this study, these seven indices (CRFNO1, CRFSO1, CRFAOa, CRFSOa, LSASS1, LSASSp, and LSAPP1) were used to assess the coherence of students' writing. All the data were input into Coh-Metrix 3.0. In addition to the results from Coh-Metrix, two raters assessed these writings using the aforementioned indices and the inter-rater reliability reached 0.92 .

\subsection{Data Analysis}

The data collected from Coh-Metrix 3.0 were processed through SPSS20.0 to measure the effects of collaborative writing on the development of the students' discourse competence in their writing. In this study, interdependent sample t-test and paired sample t-test were conducted through SPSS 20.0 to answer the three research questions.

\section{Results and Discussions}

\subsection{The Effects of Collaborative Writing on Students' Textual Cohesion}

The first research question of this study is to explore the effect of collaborative writing on senior high school students' discourse competence in terms of textual cohesion. Cohesion refers to the surface structural features in sentences and paragraphs that connect different parts together (Halliday \& Hasan, 1976; Crystal, 1992). Students' writings were analyzed by Coh-Metrix 3.0 and eight indices were used for the analysis of textual cohesion. The independent T-test was performed by SPSS 20.0 to verify if significant differences exist 
between the control and the experimental class in terms of the students' discourse competence. The result of students' immediate posttest in the control class and the experimental class were showed in Table 1.

Table 1. Comparison of the immediate posttest scores from the two classes

\begin{tabular}{ccccccc}
\hline Class & $\mathbf{N}$ & $\mathbf{M}$ & SD & $\boldsymbol{t}$ & df & $\boldsymbol{p}$ \\
\hline Control & 60 & 2.413 & 5.071 & -3.271 & 131 & $.032 * * *$ \\
Experimental & 60 & 3.735 & 4.190 & & & \\
\hline
\end{tabular}

Note. ${ }^{* * *} \mathrm{p}<.05 ; \mathrm{M}=$ mean; $\mathrm{SD}=$ standard deviation; $\mathrm{t}=$ significance test value of regression parameters; $\mathrm{df}=$ degree of freedom; $\mathrm{p}=\mathrm{p}$-value.

It is easily seen from Table 1, the mean score of the experimental class is 3.735, which is much higher (1.322) than that (2.413) of the control class. The standard deviation of the control class is 5.071 and that of the experimental class is 4.190, suggesting that the dispersion level of the experimental class is lower than that of the control class. Besides, the $t$ value is -3.271 andp $=0.032<0.05$, which indicated that there were significant differences between these two classes in immediate posttest. Based on the above data, it can be concluded that collaborative writing is more effective than traditional writing teaching method in cultivating students' discourse competence in terms of textual cohesion.

Paired sample T-test was performed to illustrate the effect of collaborative writing on students' discourse competence in terms of textual cohesion. The result was showed in Table 2.It can be seen in the above table, the textual cohesion of students' writing in the experimental class has been enhanced, which was indicated by the increase of mean score from 2.289 to 2.835 . In other words, the application of collaborative writing in writing class has increased the textual cohesion level of students by $23.8 \%$, compared with their initial ability. Besides, $t=$ -3.971 and $\mathrm{p}=0.03<0.05$, which illustrated that there was significant difference statistically before and after the experiment in the experimental class. Thus, the discourse competence of students in terms of textual cohesion has been noticeably improved. Meanwhile, the mean score of the control class did not change much, with an increase of 0.043 between the pretestand the immediate posttest, and the $\mathrm{p}$ value is $0.081>0.05$, which indicated there is no significant difference between these two tests. Therefore, according to the above data, it is easy to see that collaborative writing is more effective than traditional writing teaching method in developing students' textual cohesion.

Table 2. Comparison of the two class' scores between the pretest and immediate posttest

\begin{tabular}{llllllll}
\hline Class & Test & $\mathbf{N}$ & $\mathbf{M}$ & SD & $\boldsymbol{t}$ & df & $\boldsymbol{p}$ \\
\hline Experimental & $\mathrm{P}$ & 60 & 2.289 & 4.873 & -3.971 & 59 & $.003 * * *$ \\
Control & $\mathrm{I}$ & 60 & 2.835 & 4.190 & & & \\
& $\mathrm{P}$ & 60 & & & & & \\
& $\mathrm{I}$ & 60 & 2.110 & 5.197 & -1.892 & 59 & .081 \\
& & & 2.153 & 5.071 & & & \\
\hline
\end{tabular}

Note. ${ }^{* * *} \mathrm{p}<.05 ; \mathrm{P}=$ pretest; $\mathrm{I}=$ immediate posttest; $\mathrm{M}=$ mean; $\mathrm{SD}=$ standard deviation; $\mathrm{t}=$ significance test value of regression parameters; $\mathrm{df}=$ degree of freedom; $p=p$-value. 
A delayed posttest was designed to verify whether collaborative writing has a long-time effect on improving the students' textual cohesion. It was carried out in the tenth week, two weeks after the end of the experiment. Paired sample t-test was applied to compare the immediate posttest and delayed posttest scores of the two classes. The descriptive statistics of the paired sample $\mathrm{T}$ test was showed in 3 .

Table 3. Descriptive statistics of the immediate and delayed posttest scores from the two classes

\begin{tabular}{cllccc}
\hline Class & Test & N & Mean & SD & SEM \\
\hline Control & I & $\mathbf{6 0}$ & $\mathbf{2 . 1 5 3}$ & $\mathbf{5 . 0 7 1}$ & $\mathbf{. 7 3 8}$ \\
& D & 60 & $\mathbf{2 . 1 1 6}$ & $\mathbf{5 . 1 6 4}$ & $\mathbf{. 7 5 9}$ \\
Experimental & I & $\mathbf{6 0}$ & $\mathbf{2 . 8 5 9}$ & $\mathbf{4 . 1 9 0}$ & $\mathbf{. 4 8 3}$ \\
& D & $\mathbf{6 0}$ & $\mathbf{2 . 7 0 3}$ & $\mathbf{4 . 0 6 3}$ & $\mathbf{. 5 1 3}$ \\
\hline
\end{tabular}

Note. $\mathrm{N}=$ number of students; $\mathrm{M}=$ mean; $\mathrm{SD}=$ standard deviation; $\mathrm{SEM}=$ Standard Error of Mean.

Table 3 shows clearly that the mean score of students' cohesion level in the control class decreased to 2.116, while the mean score of the experimental class decreased to 2.703. Although the mean score of the experimental class (0.156) decreased more significantly than that of the control class (0.037), the mean score of students' cohesion level in the experimental class is still higher than that of students' cohesion level in the control class.

It can be seen clearly from Table 4 that the Sig. (2-tailed) of the control class is 0.326 and the Sig. (2-tailed) of the experimental class is 0.124 , suggesting that there is no significant difference between the immediate posttest and the delayed posttest in these two classes. In other words, the discourse competence in terms of textual cohesion of the students in the experimental class did not change drastically after the experiment.

Table 4. Comparison of the difference of the two classes' scores between immediate and delayed posttest $(\mathrm{N}=120)$

\begin{tabular}{llllllll}
\hline & & \multicolumn{3}{l}{ 95\%CID } & $t$ & df & Sig.(2-tailed) \\
\hline Class & Test & M(SD) & Lower & Upper & & & \\
\hline Control & I-D & $.037(2.582)$ & -.716 & 1.602 & 1.309 & 59 & .326 \\
\hline Experimental & I-D & $.156(2.095)$ & -.235 & 1.960 & & 59 & .124 \\
\hline
\end{tabular}

Note. $\mathrm{I}=$ immediate posttest $\mathrm{D}=$ delayed posttest $\mathrm{M}=$ mean; $\mathrm{SD}=$ standard deviation; $\mathrm{CID}=$ confidence interval of the difference; $t=$ significance test value of regression parameters; $\mathrm{df}=$ degree of freedom; $\mathrm{Sig}=$ significance.

From the above analysis, it is safe to conclude that collaborative writing exerts positive influence on the development of senior high school students' discourse competence in terms of textual cohesion. It is quite clear that the mean scores of the experimental class in the pretest and immediate posttest has increased more than that of the control class in these two 
tests.It is also clear that the application of collaborative writing in senior high school English writing class is beneficial for sustaining the improvement of students' textual cohesion.

\subsection{The Effects of Collaborative Writing on Students' Textual Coherence}

The second research question concerns the effect of collaborative writing on senior high school students' discourse competence in terms of textual coherence. Coherence is considered as the semantic association that exists in a discourse (Halliday \& Hasan, 1976; Hu, 1994; Werth, 1999), and it is distinct from cohesion. To assess students' achievement in coherence, they are required to complete an immediate posttest in the eighth week of this study and a delayed posttest in the tenth week of this study. Theirwritings were analyzed by Coh-Metrix 3.0. Based on Liang (2006), among the 106 indices in Coh-Metrix 3.0, 7 were selected for the analysis of textual coherence. The data of textual coherence were input into SPSS 20.0. First, the independent sample T-test was performed to analyze the textual coherence scores gained experimental class and the control class. The result was showed in Table 6.

Table 6. Comparison of the immediate posttest scores from the two classes

\begin{tabular}{ccccccc}
\hline Class & $\mathbf{N}$ & Mean & SD & $\boldsymbol{t}$ & df & $\boldsymbol{p}$ \\
\hline Control & 60 & 2.105 & 5.136 & -2.153 & 118 & $.008^{* * *}$ \\
Experimental & 60 & 2.483 & 4.692 & & & \\
\hline
\end{tabular}

Note. ${ }^{* * *} \mathrm{p}<.05 ; \mathrm{M}=$ mean; $\mathrm{SD}=$ standard deviation; $\mathrm{t}=$ significance test value of regression parameters; $\mathrm{df}=$ degree of freedom; $\mathrm{p}=\mathrm{p}$-value.

From the above table, we can see that the mean score of the experimental class is 2.483, which is higher (0.378) than that of the control class (2.105). It is clear that the experimental

class outperformed the control class in textual coherence.Moreover, the standard deviation of the experimental class (4.692) is less (0.444) than that of the control class (5.136), indicating indicated the textual coherence scoresgained by the experimental class are at a lower dispersion degree than the ones gained by the control class.In addition, the above data suggestthe existence of a significant difference $(t=2.513, \mathrm{p}=0.008<0.05)$ between the two classes in the immediate posttest scores. As a result, it seems that collaborative writing is more effective than traditional writing teaching methodin fostering senior high school students' textual coherence.

To further reveal the effect of collaborative writing on students' textual coherence, paired sample $t$ test was performed to analyze thepretest and immediate posttest scores gained by these two classes. The results are showed in Table 7. 
Table 7. Comparison of the two class' scores between the pretest and immediate posttest

\begin{tabular}{|c|c|c|c|c|c|c|c|}
\hline Class & Test & $\mathbf{N}$ & $\mathbf{M}$ & SD & $t$ & df & $p$ \\
\hline \multirow[t]{2}{*}{ Experimental } & $\mathrm{P}$ & 60 & 2.289 & 4.873 & -5.108 & 59 & $.003 * * *$ \\
\hline & I & 60 & 2.483 & 4.692 & & & \\
\hline \multirow[t]{2}{*}{ Control } & $\mathrm{P}$ & 60 & 2.110 & 5.197 & -2.194 & 59 & .079 \\
\hline & I & 60 & 2.105 & 5.136 & & & \\
\hline
\end{tabular}

Note. ${ }^{* * *} \mathrm{p}<.05 ; \mathrm{P}=$ pretest; $\mathrm{I}=$ immediate posttest; $\mathrm{M}=$ mean; $\mathrm{SD}=$ standard deviation; $\mathrm{t}=$ significance test value of regression parameters; $\mathrm{df}=$ degree of freedom; $\mathrm{p}=\mathrm{p}$-value.

From Table 7 above, it is clear that there is not a big difference between the pretest scores gained by the two classes. However, after the teaching experiment, the mean score of the experimental class raised from 2.289 to 2.483 in the immediate posttest, while that of the control class decreased from 2.110 to 2.105. Similar to textual cohesion scores, the students made significant progress in textual coherence scores $(t=5.108, \mathrm{p}=0.003<0.05)$ between the pretest and immediate posttest. In contrast with the experimental class, the mean score gained by the control class in the pretest and the immediate posttest only changed slightly. Additionally, for the control class, $\mathrm{p}=0.079>0.05$, suggesting that there was not any significant difference between these two tests. Therefore, it can be concluded that the experimental class outperformed the control class in the growth of textual coherence.

To assess the long-term effect of collaborative writing on senior high school students' textual coherence, a delayed posttest was performed in the tenth week, two weeks later after the experiment. Table 8 presents the delayed posttest scores analyzed through the paired sample T-test.The results shown in Table 8demonstrate the mean score of the control class increases from 2.105 to 2.163 , while for the experimental class, the mean score changed from 2.483 to 2.379 .

Table 8. Descriptive statistics of the immediate and delayed posttest scores from the two classes

\begin{tabular}{lllccc}
\hline Class & Test & N & M & SD & SEM \\
\hline Control & I & 60 & 2.105 & 5.136 & .769 \\
& D & 60 & 2.163 & 5.009 & .853 \\
Experimental & I & 60 & 2.483 & 4.692 & .662 \\
& D & 60 & 2.379 & 4.998 & .704 \\
\hline
\end{tabular}

Note. $\mathrm{N}=$ number of students; $\mathrm{M}=$ mean; $\mathrm{SD}=$ standard deviation; $\mathrm{SEM}=$ Standard Error of Mean.

It is easy to see from the Table 9 that for the experimental class, there is no significant difference between the immediate posttest and delayed posttest scores ( $\mathrm{Sig}=0.144$ ). Likewise, the control class did not differ in their textual coherence between the immediate posttest and the delayed posttest ( $\mathrm{Sig}=0.370)$. Nevertheless, it is noteworthy that the experimental class' mean score $(0.104)$ is higher than that $(0.058)$ of the control class, suggesting that the development of textual coherence maintained to a greater extent, and 
therefore reflecting the long-term effect of collaborative writing.

Table 9. Comparison of the difference of the two classes' scores between immediate and delayed posttest $(\mathrm{N}=120)$

\begin{tabular}{|c|c|c|c|c|c|c|c|}
\hline & & & $95 \% \mathrm{CIL}$ & & $t$ & df & Sig.(2-tailed) \\
\hline Class & Test & $\mathrm{M}(\mathrm{SD})$ & Lower & Upper & & & \\
\hline Control & $\mathrm{I}-\mathrm{D}$ & $.058(2.559)$ & -.615 & 1.703 & 1.513 & 59 & .370 \\
\hline Experimental & I-D & $.104(2.286)$ & -.304 & 2.007 & & 59 & .144 \\
\hline
\end{tabular}

Note. $\mathrm{I}=$ immediate posttest; $\mathrm{D}=$ delayed posttest; $\mathrm{M}=$ mean; $\mathrm{SD}=$ standard deviation; $\mathrm{CID}$ $=$ confidence interval of the difference $\mathrm{t}=$ significance test value of regression parameters; $\mathrm{df}$ $=$ degree of freedom; $\mathrm{Sig}=$ significance .

Based on the above analysis, it is safe the draw the conclusion that collaborative writing appeared to have a positive effect on senior high school students' textual coherence. The experimental class scored significantly higher than the control class in the immediate and delayed tests, and their development in textual coherence seemed to last longer than the control class.

This study explored the effect of collaborative writing on the development of Chinese senior high school students' discourse competence in terms of textual cohesion and textual coherence. Results from the pretest, immediate posttest and delayed posttest showed that collaborative writing played a positive role in fostering student's discourse competence. Specifically, compared with the control class, students in the experimental class improved their textual cohesion and coherence both in the immediate and delayed posttests, suggesting the benefits of collaborative writing for the development of both short-term and long-term discourse competence.

Several possible reasons may account for the positive effects of collaborative writing. First of all, in this study, students in the experimental class were assigned into 30 pairs according to the results of their pretest and cooperated with their pairs to produce a composition. Some studies showed that the second language development of students can be facilitated when students work in pairs (Ellis, 2003; Garcia Mayo, 2007; Lantolf, 2000). Students discussed and negotiated with their partners when they worked in pairs, and the negotiation they engage in helped them practice what they had learned in class. According to interaction hypothesis proposed by Long (1981), students pay more attention to the linguistic structures when negotiating meaning with each other, which in turns facilitate their L2 development. Furthermore, the feedback they receive during negotiated interaction is beneficial for their understanding and retention of vocabulary, morphology and syntax (Long, 1996).

From the viewpoint of Sociocultural theory, during negotiated interaction, students jointly produce collaborative dialogue, the kind of dialogue in which students build L2 knowledge and solve L2 problems (Swain, 2000). Collaborative dialogue is claimed to be source of L2 learning (Swain \& Watanabe, 2019). It offers students assistance in many ways, including clarifying misunderstanding on L2 and solving writing-related problems (Yeh, H.-C., 2014). In the present study, when producing compositions collaboratively with their peers, students 
encountered problems with cohesion and coherence, and they needed to solve these problems through continuous reflection and oral explanation. Throughout the collaboration, they engaged in the cognitive activities that mediated the co-construction of linguistic knowledge and enabled them to obtain more in-depth and comprehensive understanding of the cohesion and coherence in the text. This higher-level cognition was subsequently internalized in their minds and embodied in their own writing.

Additionally, during peer-peer collaboration, students provided scaffolded assistance to each other in the ZPD and the acquisition of L2 discourse competence. In the present study, students with higher level of discourse competence were paired with students with lower level. Since students with low level were required to complete tasks that were somewhat beyond their current L2 ability, it was of importance for them to seek assistance from students with higher level. From a sociocultural perspective, this was the occasion where peer-peer scaffolding took place. Scaffolding initially refers to the assistance that adults provide to children in solving the problems that children are not able to solve on their own (Wood, Bruner \& Ross, 1976). In peer-peer interaction, students offer assistance to each other and pool their linguistic repertoire together in face of L2 problems (e.g., Donato, 1994; Ohta, 2000). In offering scaffolded assistance to each other, students in the present study were able to produce a coherent and cohesive composition through joint efforts and developed their discourse immediately upon finishing collaborative writing, on the one hand; student with lower level, who might had greater difficulty with the cohesion and coherence of the text, received assistance from students with higher levels and the teacher, and thereby transcended their ZPD, achieved a higher level of discourse competence, incorporated the co-constructed knowledge during discussion into their own composition, and eventually maintained the long-term effect of .

Another factor concerns peer feedback. Many studies showed that peer feedback is beneficial for students to improve their writing quality (Dheram, 1995; Villamil \& De Guerrere, 1998; Tsui \& Ng 2000). In this study, students received feedback both from their peers and their teacher. Particularly, after students finish their writing, they exchange their writings and evaluate the quality of their partners' writing in terms of the correct use of cohesion and coherence. Peer feedback in written or spoken form was provided after their evaluation. Then the teacher collected and assessed all the students' written work, followed by teacher feedback given in written and oral form. Peer feedback not only helped students identify the errors in their writing but also enabled the peer readers to realize the errors they were likely to commit (Dheram, 1995; Clifford, 1981; Graham \& Perin, 2007). The combination of peer and teacher feedback was crucial for students to notice both the positive and negative evidence of the use of cohesion and coherence, and by extension, the development of their discourse competence.

\section{Conclusion and Pedagogical Implications}

Findings of the present study showed that the mean scores of textual cohesion and coherence of the experimental class is higher than that of the control class. Therefore, collaborative writing seemed to have a positive, short-term and long-term effect on the development of 


\section{I Macrothink}

Chinese senior high school students' discourse competence.

This study has several implications for teaching writing. First of all, students need to learn how to collaborate with their peers, provide each other scaffolded assistance, and offer each other useful feedback. They need to know how to internalize the co-constructed knowledge about cohesion and coherence based on their discussion with their peers so that they can traverse their ZPD more efficiently and smoothly. Additionally, teachers should be aware of the kind of student grouping that are more suitable for the occurrence of scaffolding, and provide intervention in a timely fashion when students encounter difficulty during collaborative writing.

There are some limitations for this study. The first one is the length of the study. For the reason that both the students and the teacher need time to be familiar with collaborative writing, the duration of the study, ten weeks, may affect the results of the study. In addition, all the 120 participants in this study are basically intermediate level learners of English, and they have very limited exposure to peer collaboration and English writing, which may detract from the generalization of the results. Therefore, for future studies, participants should be given more time to be acquainted with the operation of collaborative writing and be better prepared. Additionally, a larger sample size and more indices from Coh-Metrix 3.0 are necessary to determine the extent to which collaborative writing contributes to the development of students' discourse competence.

\section{Acknowledgments}

This paper is part of results of the Youth Project supported by Hunan Provincial Planning Office of Social Sciences (Grant No. 17YBQ076).

\section{References}

Abrams, Z. I. (2019). Collaborative writing and text quality in Google Docs. Language Learning \& Technology, 23(2), 22-42.

Aydin, Z., \& Yildiz, S. (2014). Using wikis to promote collaborative EFL writing. Language Learning and Technology, 18(1), 160-180.

Badger, R., \& White, G. (2000). A process genre approach to teaching writing. ELT journal, 54(2), 153-160. https://doi.org/10.1093/elt/54.2.153

Bamberg, B. (1983). What makes a text coherent?. College Composition and Communication, 34(4), 417-429. https://doi.org/10.2307/357898

Belcher, D. D. (1990). Peer vs. teacher response in the advanced composition class. Issues in Writing, 2(2), 128.

Biber, D. (1991). Variation across speech and writing. Cambridge University Press.

Bikowski, D., \& Vithanage, R. (2016). Effects of web-based collaborative writing on individual L2 writing development. Language Learning \& Technology, 20(1), 79-99.

Cai, K. G. (2011). A comparative study of online peer feedback and teacher feedback for 


\section{Macrothink}

International Journal of Linguistics

ISSN 1948-5425

2020, Vol. 12, No. 4

Chinese college students in English writing. Foreign Language, 2, 65-72.

Canale, M. (1983). On some dimensions of language proficiency. The Ontario Institute for Studies in Education.

Canale, M., \& Swain, M. (1980). Theoretical bases of communicative approaches to second language teaching and testing. Applied Linguistics, 1(1), 1-47. https://doi.org/10.1093/applin/1.1.1

Carter, R., \& McCarthy, M. (1997). Exploring spoken English (Vol. 2). Cambridge University Press.

Celce-Murcia, M., \& Olshtain, E. (2005). Discourse-Based Approaches: A New Framework for Second Language Teaching and Learning. In Handbook of research in second language teaching and learning (pp. 753-766). Routledge.

Celce-Murcia, M., Brinson, D., \& Goodwin, G. (1983). English pronunciation: A course for teachers of English to speakers of other languages.

Celce-Murcia, M., Dörnyei, Z., \& Thurrell, S. (1995). Communicative competence: A pedagogically motivated model with content specifications. Issues in Applied Linguistics, 6(2), 5-35.

Challob, A. A. I., Bakar, N. A., \& Latif, H. (2016). Collaborative Blended Learning Writing Environment: Effects on EFL Students' Writing Apprehension and Writing Performance. English Language Teaching, 9(6), 229-241. https://doi.org/10.5539/elt.v9n6p229

Cook, G. (1989). Discourse. Oxford: Oxford University Press.

Crosthwaite, P. (2011). The Effect of Collaboration on the Cohesion and Coherence of L2 Narrative Discourse between English NS and Korean L2 English users. Asian EFL Journal, 13,4 .

Crystal, D. (1992). An Encyclopedia Dictionary of Languages. Oxford: Blackwell.

Dheram, P. K. (1995). Feedback as a two-bullock cart: A case study of teaching writing. ELT Journal, 49(2), 160-168. https://doi.org/10.1093/elt/49.2.160

Ede, L. S., \& Lunsford, A. A. (1992). Singular texts/plural authors: Perspectives on collaborative writing. SIU Press.

Elola, I. (2010). Collaborative writing: Fostering foreign language and writing conventions development. Language Learning \& Technology, 14(3), 51-71.

Falchikov, N. (1995). Peer feedback marking: Developing peer assessment. Innovations in Education and Training International, $32(2), \quad$ 175-187. https://doi.org/10.1080/1355800950320212

$\mathrm{Fu}, \mathrm{H}$. (2013). Discourse convergence and the cultivation of coherent consciousness and ability. Foreign Language Teaching in Primary and Secondary Schools, 8, 13-17. 


\section{I Macrothink}

International Journal of Linguistics

ISSN 1948-5425

2020, Vol. 12, No. 4

Graham, S., \& Perin, D. (2007). What we know, what we still need to know: Teaching adolescents to write. Scientific Studies of Reading, 11(4), 313-335. https://doi.org/10.1080/10888430701530664

Grami, G. M. A. (2012). Online Collaborative Writing for ESL Learners Using Blogs and Feedback Checklists. English Language Teaching, 5(10), 43-48. https://doi.org/10.5539/elt.v5n10p43

Halliday, M. A. K., \& Hasan, R. (1989). Language, context, and text: Aspects of language in a social-semiotic perspective.

Halliday, M. A. K., \& Hasan, R. (2014). Cohesion in English. Routledge. https://doi.org/10.4324/9781315836010

Halliday, M. A. K., \& Kress, G. R. (1976). System and function in language: Selected papers. Oxford University Press.

Halliday, M., Matthiessen, C. M., \& Matthiessen, C. (2014). An introduction to functional grammar. Routledge. https://doi.org/10.4324/9780203783771

Hedgcock, J., \& Lefkowitz, N. (1992). Collaborative oral/aural revision in foreign language writing instruction. Journal of Second Language Writing, 1(3), 255-276. https://doi.org/10.1016/1060-3743(92)90006-B

Hoey, M. (1991). Patterns of lexis in text (Vol. 299). Oxford: Oxford University Press.

Hsu, H. C., \& Lo, Y. F. (2018). Using wiki-mediated collaboration to foster L2 writing performance. Language Learning \& Technology, 22(3), 103-123.

$\mathrm{Hu}, \mathrm{Zh}$. L. (1994). The convergence and coherence of discourse. Shanghai: Shanghai Foreign Language Education Publishing.

Huang, G. W. (1988). Summary of Discourse Analysis. Hunan Education Press.

Hymes, D. (1972). On communicative competence. Sociolinguistics, 269-293.

Jiang, J. L. (2016). Application of Coh-Metrix tools in foreign language teaching and research. Chinese Foreign Language, 5, 58-65.

Kessler, G., Bikowski, D., \& Boggs, J. (2012). Collaborative writing among second language learners in academic web-based projects. Language Learning \& Technology, 16(1), 91-109.

Kormos, J. (2014). Differences across modalities of performance. Task-Based Language Learning-Insights From and for L2 Writing, 193-216. https://doi.org/10.1075/tblt.7.08kor

Li, M., \& Zhu, W. (2017). Good or bad collaborative wiki writing: Exploring links between group interactions and writing products. Journal of Second Language Writing, 35, 38-53. https://doi.org/10.1016/j.jslw.2017.01.003

Liang, M. Ch. (2006). Study of the consistency of the learner's written discourse. Doctoral dissertation. 
Liu, Ch. D. (1999). Teaching Discourse. Shanghai Foreign Language Education Press.

Long, M. H. (1981). Input, interaction, and second-language acquisition. Annals of the New $\begin{array}{llll}\text { York Academy } & \text { of } & \text { 259-278. }\end{array}$ https://doi.org/10.1111/j.1749-6632.1981.tb42014.x

Lowry, P. B., Curtis, A., \& Lowry, M. R. (2004). Building a taxonomy and nomenclature of collaborative writing to improve interdisciplinary research and practice. The Journal of Business Communication (1973), 41(1), 66-99. https://doi.org/10.1177/0021943603259363

Mangelsdorf, K. (1992). Peer reviews in the ESL composition classroom: What do the students think?. ELT Journal, 46(3), 274-284. https://doi.org/10.1093/elt/46.3.274

McCulley, G. A. (1985). Writing quality, coherence, and cohesion. Research in the Teaching of English, 269-282.

Miller, C. R. (1984). Genre as social action. Quarterly Journal of Speech, 70(2), 151-167. https://doi.org/10.1080/00335638409383686

Min, H. T. (2005). Training students to become successful peer reviewers. System, 33(2), 293-308. https://doi.org/10.1016/j.system.2004.11.003

Ministry of Education of the People's Republic of China. (2018). General High School English Curriculum Standard (2017 ed.). Beijing.

Mo, J. H. (2007). Peer review: Improving the autonomy of college students' writing. Doctoral dissertation.

Namaziandost, E., Esfahani, F. R., Nasri, M., \& Mirshekaran, R. (2018). The effect of gallery walk technique on pre-intermediate EFL learners' speaking skill. Language Teaching Research Quarterly, 8, 1-15.

Namaziandost, E., Saray, A. A., \& Esfahani, F. R. (2018). The effect of writing practice on improving speaking skill among pre-intermediate EFL learners. Theory and Practice in Language Studies, 8(12), 1690-1697. https://doi.org/10.17507/tpls.0812.16

Nelson, G. L., \& Murphy, J. M. (1993). Peer response groups: Do L2 writers use peer comments in revising their drafts?. TESOL Quarterly, 27(1), 135-141. https://doi.org/10.2307/3586965

Paulus, T. M. (1999). The effect of peer and teacher feedback on student writing. Journal of Second Language Writing, 8(3), 265-289. https://doi.org/10.1016/S1060-3743(99)80117-9

Prodromou, L. (1995). The backwash effect: from testing to teaching. English Language Teaching Journal, 21(1), 1-25. https://doi.org/10.1093/elt/49.1.13

Rayers, C. (1987). Writing Should Be Sharing. Reading, 21(2), 115-24. https://doi.org/10.1111/j.1467-9345.1987.tb00631.x

Ross, J. A. (1995). Effects of feedback on student behavior in cooperative learning groups in a grade 7 math class. The Elementary School Journal, 96(2), 125-143. 
https://doi.org/10.1086/461818

Shang, Y. Zh. (2015). To develop students' Written Expression skills in English from the point of view of text convergence. Teaching and Management, 27, 13-28.

Shao, M. L. (2009) Peer evaluation in the English professional writing teaching research. Foreign Language Teaching Theory and Practice, 2, 47-53.

Storch, N. (2002). Patterns of interaction in ESL pair work. Language Learning, 52(1), 119-158. https://doi.org/10.1111/1467-9922.00179

Storch, N. (2011). Collaborative writing in L2 contexts: Processes, outcomes, and future directions. Annual Review of Applied Linguistics, 31, 275-288. https://doi.org/10.1017/S0267190511000079

Strobl, C. (2013). Affordances of Web 2.0 technologies for collaborative advanced writing in a foreign language. Calico Journal, 31(1), 1-18. https://doi.org/10.11139/cj.31.1.1-18

Swain, M., Kinnear, P., \& Steinman, L. (2015). Sociocultural theory in second language education: An introduction through narratives (Vol. 11). Multilingual matters. https://doi.org/10.21832/9781783093182

Tribble, C., \& Jones, G. (1997). Concordances in the classroom: A resource guide for teachers. Athelstan.

Tsui, A. B., \& Ng, M. (2000). Do secondary L2 writers benefit from peer comments?. Journal of Second Language Writing, 9(2), 147-170. https://doi.org/10.1016/S1060-3743(00)00022-9

Villamil, O. S., \& Guerrero, M. C. D. (1998). Assessing the impact of peer revision on L2 writing. Applied Linguistics, 19(4), 491-514. https://doi.org/10.1093/applin/19.4.491

Watanabe, Y., \& Swain, M. (2007). Effects of proficiency differences and patterns of pairinteraction on second language learning: Collaborative dialogue between adult ESL learners. Language Teaching Research, 11(2), 121-142. https://doi.org/10.1177/136216880607074599

Weissberg, R. (2006). Connecting speaking \& writing in second language writing instruction. Ann Arbor: University of Michigan Press. https://doi.org/10.3998/mpub.6702

Wen, Q. F. (1999). Oral English Test and Teaching. Shanghai: Shanghai Foreign Language Education Press.

Werth, M. R. (1999). The Influence of Coherence in Text Linguistics. Cambridge: Cambridge University Press.

Wigglesworth, G., \& Storch, N. (2009). Pair versus individual writing: Effects on fluency, complexity and accuracy. Language Testing, 26(3), 445-466. https://doi.org/10.1177/0265532209104670

Wigglesworth, G., \& Storch, N. (2012). What role for collaboration in writing and writing 


\section{Macrothink}

International Journal of Linguistics

ISSN 1948-5425 2020, Vol. 12, No. 4

feedback. Journal of Second Language Writing, 21(4), 364-374. https://doi.org/10.1016/j.jslw.2012.09.005

Yang, M., Badger, R., \& Yu, Z. (2006). A comparative study of peer and teacher feedback in a Chinese EFL writing class. Journal of Second Language Writing, 15(3), 179-200. https://doi.org/10.1016/j.jslw.2006.09.004

Zhai, X. B. (2007). English Writing Teaching: Optimised Peer Feedback. Foreign Language Teaching, 3, 47-57.

Zhang, D. L. (2006). A coherent study of macro principles. Foreign Language and Foreign Language Teaching, (10), 7-10.

Zhao, H. (2010). Investigating learners' use and understanding of peer and teacher feedback on writing: A comparative study in a Chinese English writing classroom. Assessing Writing, 15(1), 3-17. https://doi.org/10.1016/j.asw.2010.01.002

Zhuang, W. (2011). On the language learner's language skills. Journal of Hubei Radio and Television University, 31(7), 106-107.

Zimmet, N. (2000). Engaging the disaffected: Collaborative writing across the curriculum projects. The English Journal, 90(1), 102-106. https://doi.org/10.2307/821739

\section{Copyrights}

Copyright for this article is retained by the author(s), with first publication rights granted to the journal.

This is an open-access article distributed under the terms and conditions of the Creative Commons Attribution license (http://creativecommons.org/licenses/by/4.0/) 